\title{
Phenotypic correlation between productivity traits in the Lithuanian dairy cattle breeds
}

\author{
Lina Anskiené ${ }^{1}$, \\ Virginija Žoštautienè ${ }^{1}$, \\ Vida Juozaitiené ${ }^{1}$, \\ Arūnas Šileika ${ }^{1}$, \\ Aleksandras Muzikevičius ${ }^{1}$, \\ Stepas Grikšas \\ Birutė Šlyžiene் ${ }^{1}$ \\ ${ }^{1}$ Veterinary Academy, \\ Lithuanian University of Health Sciences, \\ Tilžés St. 18, LT-47181 Kaunas \\ ${ }^{2}$ Russian State Agrarian University - \\ Moscow Agricultural Academy \\ named after K. A. Timiryazev, \\ Timiryazevskaya St. 49, \\ $R U-127550$, Moscow \\ E-mail:biometrija@lva.lt; \\ anskiene@lva.lt
}

The aim of the work was to perform a research of phenotypic correlations between milk production and composition traits in Lithuanian dairy cattle breeds according to the data of all controlled cows $(n=1,489,264)$ during the period 2003-2012.

The analysis showed strong positive, statistically significant correlations in all analyzed breeds between milk kg and fat kg correlations ranged from $r=0.915$ in Lithuanian White-backed to $r=0.948(p<0.001)$ in Lithuanian Ash-grey controlled cows, and between milk $\mathrm{kg}$ and protein $\mathrm{kg}$ correlations ranged from $\mathrm{r}=0.969$ in Lithuanian White-backed to $\mathrm{r}=0.984(\mathrm{p}<0.001)$ in Lithuanian Red, and between fat $\mathrm{kg}$ and protein $\mathrm{kg}$ correlations ranged from $\mathrm{r}=0.928$ in Lithuanian Black-and-White to $\mathrm{r}=0.949(\mathrm{p}<0.001)$ in Lithuanian Ash-grey controlled cows. Low positive, statistically significant correlations in all analyzed breeds were estimated between fat and protein percentages. Correlations ranged from $\mathrm{r}=0.256$ in Lithuanian Black-and-White to $r=0.353(p<0.001)$ in Lithuanian Ashgrey controlled cows. Also low positive, statistically significant correlations in all analyzed breeds were estimated between milk $\mathrm{kg}$ and protein percentages, $r=0.020(p<0.01)$ in Lithuanian Red and $r=0.042(p<0.001)$ in Lithuanian Black-and-White controlled cows.

Key words: Lithuanian White-backed, Lithuanian Ash-grey, Lithuanian Black-and-White, Lithuanian Red, correlations

\section{MATERIALS AND METHODS}

Data from the Lithuanian Agricultural Information and Rural Business Centre of 1,489,264 controlled cows during the period 2003-2012 were analysed.

The data were made from Lithuanian dairy cattle breeds records which consisted of 0.29 percent Lithuanian Ash-grey, 0.25 percent Lithuanian White-backed, 76.19 percent Lithuanian Blackand-White, 23.27 percent Lithuanian Red cows.

A statistical analysis was conducted using the statistics package (SPSS for Windows 15, SPSS Inc., Chicago, IL, USA). Coefficient of phenotypic correlation was estimated by Pearson.

Linear regression was used for analysis of traits of milk production and composition in the Lithuanian dairy cattle breeds.
The reliability of difference between means (p) was found following a Student's distribution. Results were considered to be reliable when $\mathrm{p}<0.001$, $\mathrm{p}<0.01$, and $\mathrm{p}<0.05$.

\section{RESULTS AND DISCUSSION}

Knowledge of the correlations between different characters and traits of the animals has great practical importance for selection of the biological material.

The phenotypic correlation between quantitative traits describes the extent to which individuals above average for one trait tend to be above, below or near the average for other traits. It measures the linear association between traits, that is, it predicts the deviation from the population mean in one 
trait of an individual as a function of its deviation from the population mean of the other when both traits are measured in their respective phenotypic standard deviation unit (Ojedapo, 2013).

In Lithuanian food industry, the main part is composed of cattle dairy products. Milk in the farmers agricultural production structure takes up almost a quarter and dairy product exports represent about a fifth of the country's agricultural and food products exports (Kuodys, Kučas, 2007).

In 2012 in Lithuania there were 328,352 cows, from which 142,944 cows are controlled ones. The most popular breed of dairy cattle is Blackand-White, and it has 105,794 controlled cows. In Lithuania the population of Black-and-White consists of these breeds: Lithuanian, German, British Fr., Dutch, Holstein, Danish, Swedish. From all controlled cows 74 percent are cows of this breed. Lithuanian Black-and-White form a part of 48 percent of the controlled Black-andWhite cows.

The second very popular breed of dairy cattle is Red and Red-and-White with 35,188 controlled cows. This population consists of the Red, Redand-White breeds: Lithuanian, Angler, Danish, Ayrshire, Brown Swiss, German $R$ \& W, Swedish $R \& W$, Holstein. From all controlled cows 25 percent are cows of this breed. Lithuanian Red form a part of 47 percent of the controlled Red, Red-andWhite cows.

Lithuanian White-backed and Lithuanian Ashgrey form a part of less than 1 percent of all controlled cows in Lithuania.
Lithuanian White-backed and Lithuanian Ashgrey cattle are already known from the beginning of the twentieth century, however, because of the long-term uncontrolled improvement of various Black-and-White or even Red bulls, due to a massive culling from large farm herds, due to incorrect color with no regard to productivity and a number of economic factors, local breeds found themselves on the brink of extinction. Today Lithuanian White-backed and Lithuanian Ash-grey are indigenous, local Lithuanian breeds (Šveistienè, Anskienè, 2011; Urbšienè, 2004).

The milk yield of Lithuanian Ash-grey controlled cows (Fig. 1) during the period 2003-2012 increased gradually by $12.94 \%\left(\mathrm{R}^{2}=0.8178\right)$, milk protein decreased by $0.006 \%\left(\mathrm{R}^{2}=0.59\right)$, milk fat increased by $0.23 \%\left(\mathrm{R}^{2}=0.78\right)$. The milk yield of Lithuanian Black-and-White controlled cows increased gradually by $26.02 \%\left(\mathrm{R}^{2}=0.9877\right)$, milk protein decreased by $0.006 \%\left(\mathrm{R}^{2}=0.65\right)$, milk fat increased by $0.001 \%\left(\mathrm{R}^{2}=0.02\right)$. The milk yield of Lithuanian Red controlled cows also increased gradually by $32.82 \%\left(\mathrm{R}^{2}=0.9742\right)$, milk protein decreased by $0.006 \%\left(\mathrm{R}^{2}=0.14\right)$, milk fat also decreased by $0.006 \%\left(\mathrm{R}^{2}=0.62\right)$.

Milk protein is the most valuable constituent of milk (Rattray, Jelen, 1996; Pečiulaitienè ir kt., 2006; Pečiulaitiene et al., 2007) and currently is one of the economically most important dairy cattle signs in selection (Zamani et al., 2011; Gaidžiūnienė et al., 2006; Oberauskas et al., 2004). Lithuanian White-backed and Lithuanian Ash-grey cows have a good milk composition. During the

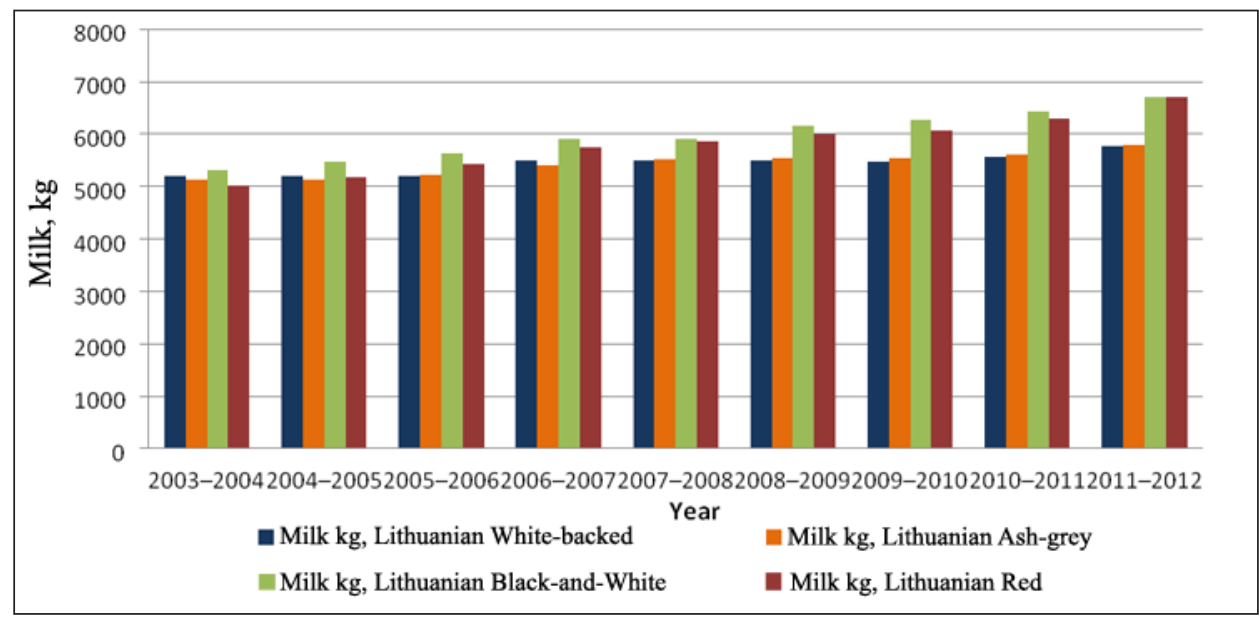

Fig. 1. Graphical representation of milk yield of controlled Lithuanian dairy cattle breeds, $\mathrm{kg}$ 
investigated period their milk fat content ranged from 4.14 to 4.42 percent, milk protein content ranged from 3.28 to 3.35 percent (Fig. 2).

The analysis showed (Figs. 1-3) that average differences between milk yield and composition of Lithuanian White-backed and Lithuanian Blackand-White are the following: Lithuanian Whitebacked milk $\mathrm{kg}$ is less by $13.35 \%(\mathrm{p}<0.01$ ), fat $\mathrm{kg}$ by $11.84 \%(\mathrm{p}<0.01)$ and protein $\mathrm{kg}$ by $13.63 \%$ $(\mathrm{p}<0.01)$.

Average differences between milk yield and composition of Lithuanian Ash-grey and Lithuanian Black-and-White are as follows: Lithuanian Ash-grey milk $\mathrm{kg}$ is less by $12.97 \%(\mathrm{p}<0.01)$, fat percentage by 0.08 ( $\mathrm{p}<0.001)$, fat $\mathrm{kg}$ by $14.28 \%$ $(\mathrm{p}<0.01)$, protein percentage by $0.02(\mathrm{p}>0.05)$, protein $\mathrm{kg}$ by $13.63 \%(\mathrm{p}<0.01)$.

Average differences between milk yield and composition of Lithuanian White-backed and Lithuanian Red are the following: Lithuanian Whitebacked milk $\mathrm{kg}$ is less by $12.83 \%$ ( $\mathrm{p}>0.05$ ), fat percentage by 0.15 ( $\mathrm{p}<0.001$ ), fat $\mathrm{kg}$ by $14.23 \%$ $(\mathrm{p}<0.1)$, protein percentage by $0.14(\mathrm{p}<0.001)$, protein $\mathrm{kg}$ by $16.66 \%(\mathrm{p}<0.01)$.

Average differences between milk yield and composition of Lithuanian Ash-grey and Lithuanian Red are as follows: Lithuanian Ash-grey milk $\mathrm{kg}$ is less by $12.46 \%(\mathrm{p}<0.1)$, fat percentage by $0.24(\mathrm{p}<0.001)$, fat $\mathrm{kg}$ by $16.61 \%(\mathrm{p}<0.01)$, protein percentage by $0.15(\mathrm{p}<0.001)$, protein $\mathrm{kg}$ by $16.66 \%(\mathrm{p}<0.01)$.

Although genetic factors have significant influence on milk protein and milk fat, its improvement in many populations is difficult because of the unfavourable correlation with cows productivity. The one-sided selection for milk production significantly reduces milk fat and protein content (Oberauskas et al., 2004).

The analysis showed (Table) that strong positive, statistically significant correlations in all analyzed breeds between milk $\mathrm{kg}$ and fat $\mathrm{kg}$ ranged from $\mathrm{r}=0.915$ in Lithuanian White-backed to $\mathrm{r}=0.948(\mathrm{p}<0.001)$ in Lithuanian Ash-grey controlled cows, and correlations between milk kg and protein $\mathrm{kg}$ ranged from $\mathrm{r}=0.969$ in Lithuanian White-backed to $r=0.984(p<0.001)$ in Lithuanian Red, and correlations between fat $\mathrm{kg}$ and protein $\mathrm{kg}$ ranged from $\mathrm{r}=0.928$ in Lithuanian Black-and-white to $r=0.949(p<0.001)$ in Lithuanian Ash-grey controlled cows.

Other scientists received almost analogical correlations. S. Baul et al. (2009) received these statistically significant, positive correlations in Romanian Black-and-White: $\mathrm{r}=0.965$, between milk kg and protein $\mathrm{kg}, \mathrm{r}=0.949$, between milk $\mathrm{kg}$ and fat $\mathrm{kg}, \mathrm{r}=0.968(\mathrm{p}<0.001)$, between fat $\mathrm{kg}$ and protein $\mathrm{kg}$.

A moderate positive correlation between milk fat and protein $\mathrm{r}=0.44(\mathrm{p}<0.01)$ and a low positive correlation between milk yield and fat percentage $(r=0.01)$, as well as between milk yield and protein percentage $(r=-0.08)$, were estimated in the Lithuanian Red and Red-and-White cattle population. Highly positive and significant correlation coefficients $r=0.84-0.97(p<0.01)$ between milk yield and milk fat and protein yields were obtained by D. Oberauskas et al. (2004, 2006). V. Juozaitiené (2003) determined reliable high

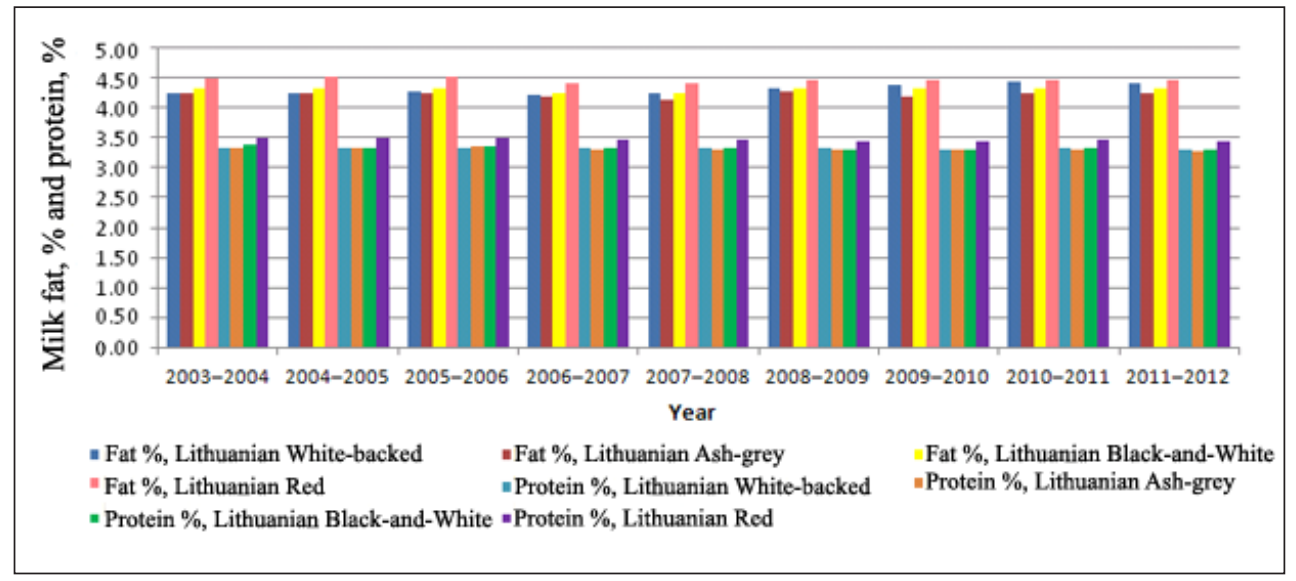

Fig. 2. Fat and protein percentages of controlled Lithuanian dairy cattle breeds, graphical representation 


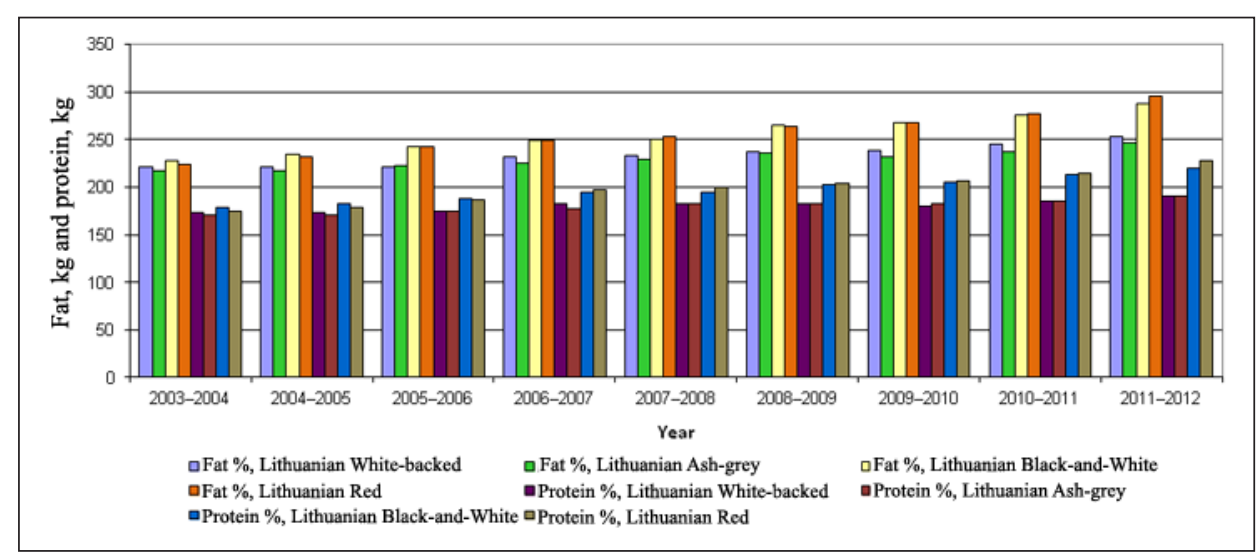

Fig. 3. Fat and protein kg of controlled Lithuanian dairy cattle breeds, graphical representation

correlation coefficients between the milk yielding capacity and milk fat and milk protein production, $r=0.88-0.96(p<0.001)$, almost the same correlation coefficients were estimated by B. L. Harris, A. E. Freeman (1992), $r=0.86-0.94$, and by L. Petrakova et al. (2011), $r=0.82-0.97(\mathrm{p}<0.001)$.

Also positive and very high correlations in milk yield and milk composition of Romanian Spotted breed heifers were estimated by other authors, Gh. Nistor et al. (2009). They have estimated positive and very significant $(\mathrm{p}<0.001)$ correlations: $\mathrm{r}=0.9873$, between milk $\mathrm{kg}$ and fat $\mathrm{kg}, \mathrm{r}=0.9568$, between fat $\mathrm{kg}$ and protein $\mathrm{kg}, \mathrm{r}=0.972$.

We estimated low positive, statistically significant correlations in all analyzed breeds, between fat and protein percentages. Correlations ranged from $\mathrm{r}=0.256$ in Lithuanian Black-and-White to $r=0.353(p<0.001)$ in Lithuanian Ash-grey controlled cows. Also low positive, statistically significant correlations in all analyzed breeds were estimated between milk kg and protein percentage, $r=0.020(\mathrm{p}<0.01)$ in Lithuanixan Red and $\mathrm{r}=0.042(\mathrm{p}<0.001)$ in Lithuanian Black-andWhite controlled cows.

\section{CONCLUSIONS}

1. The analysis showed that average differences in milk yield and milk composition of Lithuanian White-backed and Lithuanian Black-and-White are the following: less in Lithuanian Whitebacked ranging from $13.63 \%(\mathrm{p}<0.01)$ protein $\mathrm{kg}$ to $11.84 \%(\mathrm{p}<0.01)$ fat $\mathrm{kg}$. Average differences in milk yield and milk composition of Lithuanian White-backed and Lithuanian Red are as follows: Lithuanian White-backed milk $\mathrm{kg}$ is less, ranged from $16.66 \%(\mathrm{p}<0.01)$ protein $\mathrm{kg}$ to $0.14(\mathrm{p}<0.001)$ protein $\%$. Average differences in milk yield and milk composition of Lithuanian Ash-grey and Lithuanian Black-and-White are as follows: less in Lithuanian Ash-grey ranged from $14.28 \%$ ( $\mathrm{p}<0.01)$ fat $\mathrm{kg}$ to 0.02 ( $\mathrm{p}>0.1)$ protein \%. Average differences in milk yield and milk composition of Lithuanian Ash-grey and Lithuanian Red are the following: Lithuanian Ash-grey milk $\mathrm{kg}$ is less, ranged from $16.66 \%(\mathrm{p}<0.01)$ protein $\mathrm{kg}$ to $0.15(\mathrm{p}<0.001)$ protein $\%$.

2. We estimated low positive, statistically significant correlations in all Lithuanian breeds, between

Table. Correlation coefficient for Lithuanian dairy cattle breeds, controlled cows

\begin{tabular}{|c|c|c|c|c|c|c|}
\hline Breed & $\begin{array}{c}\text { Milk, } \\
\text { kg - fat, } \\
\text { kg }\end{array}$ & $\begin{array}{c}\text { Milk, } \\
\text { kg - fat, } \\
\%\end{array}$ & $\begin{array}{c}\text { Milk, } \\
\text { kg - pro- } \\
\text { tein, kg }\end{array}$ & $\begin{array}{c}\text { Milk, } \\
\text { kg - pro- } \\
\text { tein, \% }\end{array}$ & $\begin{array}{c}\text { Fat, } \\
\% \text { - pro- } \\
\text { tein, \% }\end{array}$ & $\begin{array}{c}\text { Fat, } \\
\text { kg - pro- } \\
\text { tein, kg }\end{array}$ \\
\hline Lithuanian White-backed & $0.915^{\star * *}$ & -0.040 & $0.969^{* * *}$ & 0.043 & $0.331^{\star * *}$ & $0.930^{* * *}$ \\
\hline Lithuanian Ash-grey & $0.948^{* * *}$ & 0.048 & $0.980^{\star * *}$ & 0.009 & $0.353^{\star * *}$ & $0.949^{* * *}$ \\
\hline Lithuanian Black-and-White & $0.925^{\star * *}$ & $-0.080^{* * *}$ & $0.980^{* * *}$ & $0.042^{* * *}$ & $0.256^{* * *}$ & $0.928^{\star * *}$ \\
\hline Lithuanian Red & $0.943^{\star * *}$ & $-0.105^{\star \star \star}$ & $0.984^{* * *}$ & $0.020^{\star *}$ & $0.273^{\star * *}$ & $0.948^{\star * *}$ \\
\hline
\end{tabular}


fat and protein percentages. Correlations ranged from $\mathrm{r}=0.256$ in Lithuanian Black-and-White to $r=0.353(p<0.001)$ in Lithuanian Ash-grey controlled cows. Also low positive, statistically significant correlations in all analyzed breeds were estimated between milk kg and protein percentage, $\mathrm{r}=0.020(\mathrm{p}<0.01)$ in Lithuanian Red and $\mathrm{r}=0.042(\mathrm{p}<0.001)$ in Lithuanian Black-andWhite controlled cows. The negative correlation in Lithuanian Black-and-White and Lithuanian Red cow population between milk yield and fat percentage indicated that selection for the former would decline fat percentage.

Received 10 October 2013 Accepted 13 March 2014

\section{REFERENCES}

1. Annual Report of Milk Recording. 2012. No. 74. P. 16-20.

2. Baul S., Stancein G., Cziszten L. T., Acatincai S., Tripon I., Gavojdian D., Silvia E., Bognor A. 2009. Study on phenotypic correlations among milk production and milk chemical composition. Zootechnics and Biotechnology. Vol. 42(2). P. 213216.

3. Bondesan V.; Veneto Agricoltura. 2011. Supporting Local Breed Conservation through the Linkage with Traditional Products. Agripolis. P. 30.

4. Gaidžiūnienė N., Vasiliauskas V., Jasiulevičienė E. 2006. Lithuanian Black and White Cattle Selection Program for 2006-2010 Years. P. 1-48.

5. Harris B. L., Freeman A. E. 1992. Genetic and phenotypic parameters for type and production in Guernsey dairy cows. Journal of Dairy Science. Vol. 75. Issue 4. P. 1147-1153.

6. Hof G., Tamminga S., Lenaers P. J. 1994. Efficiency of protein utilization in dairy cows. Livestock Production Science. Vol. 38. Issue 3. P. 169-178.

7. Juozaitienè V. 2003. The increasing of selection efficiency by improvement of the Black and White cattle population in Lithuania. ISSN 1392-2130. Veterinarija ir zootechnika. T. 22(44).

8. Kuodys A., Kučas V. 2007. The structural and economic changes in farmers dairy farms. Agricultural Science. Vol. 14. P. 91-98.

9. Lietuvos žemés ūkio gyvūnu genetiniai ištekliai. 2003. P. 24.

10. Malevičiūtė J., Baltrènaitė L., Miceikienė I. 2002. Domestic cattle breed diversity in Lithuania. Veterinarija ir zootechnika. T. 20(42). P. 87-91.

11. Nistor Gh., Nistor E., Bampidis V., Skapetas B. 2009. Phenotypic correlation between couple of milk production traits in Romanian spotted breed dairy heifers from S. C. Agrosem S. A. Pischia, Timis county. Zootechnics and Biotechnology. Vol. 42(2). P. 317-321.

12. Oberauskas D., Juozaitiene V., Darbutas J., Lavrinovič J., Čiukauskas V. 2004. Development of the Lithuanian Red and Red-and-White cattle production. International Scientific Conference Material: The EU Practice Implementation of the Balanced Breeding on Improvement of Lithuanian Black-and-White. Kaunas. P. 49-51.

13. Oberauskas D., Juozaitienè V., Darbutas J., Lavrinovičius J., Čiukauskas V. 2004. The influence of breed on production and reproductive traits in the Lithuanian Red and Red-and-White cattle population. Animal Breeding in the Baltics: 10th Baltic Animal Breeding Conference. Tartu, Estonia. P. 6267.

14. Ojedapo L. O. 2013. Phenotypic correlation between the external and internal egg quality traits of Pharaoh quail reared in derived savanna zone of Nigeria. Journal of Biology, Agriculture and Healthcare. Vol. 3(10). P. 80.

15. Pečiulaitienè N., Miceikienè I., Mišeikienè R. 2006. Pieno baltymų Alfa s1-Kapa kazeinų genotipų derinių paplitimas ir ryšys su Lietuvos pieninių galvijų veislių produktyvumu. Veterinarija ir zootechnika. T. 34(56). P. 56-61.

16. Pečiulaitienè N., Miceikienè I., Mišeikienė R., Krasnopiorova N., Kriauzienė J. 2007. Genetic factors influencing milk production traits in Lithuanian dairy cattle breeds. Žemès ūkio mokslai. Nr. 1. P. 32-38.

17. Petrakova L., Kerzienė S., Razmaitè V. 2011. Žinomos ir nežinomos kilmès Lietuvos žalųjų karvių produktyviosios savybès. Gyvulininkystè. T. 57. P. 3-17.

18. Rattray W., Jelen P. 1996. Protein standardization of milk and dairy products. Trends in Food Science \& Technology. Vol. 7. Issue 7. P. 227-234.

19. Šveistienė R., Anskienė L. 2011. Lithuanian Native Ash-Grey Cattle Breeding Program. P. 1-19.

20. Šveistienè R., Anskienė L. 2011. Lithuanian Native White-Backed Cattle Breeding Program. P. 1-19.

21. Tilki M., Inal S., Colak M., Garip M. 2005. Relationships between milk yield and udder measurements in Brown Swiss cows. Turkish Journal of Veterinary and Animal Sciences. P. 75-81.

22. Urbšienè D. 2004. Lietuvos vietinių šèmu ir baltnugarių karvių pieningumo ir pieno kokybès palyginimas. Gyvulininkyste. T. 45. P. 71-79.

23. Zamani P., Miraei-Ashtjani S. R., Alipour D., Aliarabi H., Saki A. A. 2011. Genetic parameters of protein efficiency and its relationships with yield traits in lactating dairy cows. Livestock Science. Vol. 138. Issue 1. P. 272-277. 
Lina Anskienė, Virginija Žoštautienè, Vida Juozaitienè, Arūnas Šileika, Aleksandras Muzikevičius, Stepas Grikšas, Biruè Šlyžienè

\section{LIETUVOS PIENINIŲ GALVIJŲ VEISLIŲ \\ FENOTIPINĖS KORELIACIJOS PAGAL PRODUK- TYVUMO POŽYMIUS NUSTATYMAS}

\section{Santrauka}

Tyrimo tikslas buvo atlikti fenotipinių koreliacijų tyrimą naudojant masinius kontroliuojamų Lietuvos pieninių galvijų veislių karvių ( $\mathrm{n}=1489264)$ pieno produktyvumo ir sudėties 2003-2012 m. duomenis.

Nustatyta stipri teigiama, statistiškai patikima visų tirtų galvijų veislių koreliacija: tarp pieno $(\mathrm{kg})$ ir riebalų $(\mathrm{kg})$ svyravo nuo $r=0,915$ Lietuvos baltnugarių iki $r=0,948$ ( $\mathrm{p}<0,001)$ Lietuvos šemųjų kontroliuojamų karvių; tarp pieno $(\mathrm{kg})$ ir baltymų $(\mathrm{kg})$ koreliacija svyravo nuo $\mathrm{r}=0,969$ Lietuvos baltnugarių iki $\mathrm{r}=0,984$ ( $\mathrm{p}<0,001)$ Lietuvos žalųjų; tarp riebalų $(\mathrm{kg})$ ir baltymų $(\mathrm{kg})$ koreliacija svyravo nuo $\mathrm{r}=0,928$ Lietuvos juodmargių iki $\mathrm{r}=0,949(\mathrm{p}<0,001)$ Lietuvos šèmųjų kontroliuojamų karvių. Žema teigiama, statistiškai patikima visų tirtų veislių galvijų koreliacija nustatyta tarp pieno riebalų (\%) ir pieno baltymų (\%). Koreliacija svyravo nuo $r=0,256$ Lietuvos juodmargių iki $r=0,353$ $(\mathrm{p}<0,001)$ Lietuvos šèmųjų kontroliuojamų karvių. Taip pat žema teigiama, statistiškai patikima koreliacija nustatyta tarp visų veislių karvių pieningumo ir pieno baltymingumo $\mathrm{r}=0,020(\mathrm{p}<0,01)$ Lietuvos žalųjų iki $\mathrm{r}=0,042(\mathrm{p}<0,001)$ Lietuvos juodmargių kontroliuojamų karvių.

Raktažodžiai: Lietuvos juodmargiai, Lietuvos žalieji, Lietuvos baltnugariai, Lietuvos šèmieji, koreliacija 